\title{
TANGGAPAN SISWA TERHADAP MODEL PENGAJARAN ADVOKASI HUBUNGANNYA DENGAN MOTIVASI BELAJAR MEREKA PADA MATA PELAJARAN FIQIH
}

\author{
Eka Abdul Hamid \\ Program Studi Pendidikan Agama Islam \\ Sekolah Tinggi Agama Islam (STAI) Sebelas April Sumedang \\ Jl. Angkrek Situ No. 19, Sumedang, 45323 Indonesia \\ Email: ekahamid23@gmail.com
}

\begin{abstract}
Abstrak
Penelitian ini berawal dari fenomena yang muncul di MA YKDC Sumedang, yakni timbulnya kesenjangan antara tanggapan siswa terhadap model pengajaran advokasi dengan motivasi belajar pada mata pelajaran Fiqih. Masih terdapat $70 \%$ atau berjumlah 30 siswa yang tidak semangat untuk belajar yang dilihat dari sikap mereka yang tidak antusias, acuh tak acuh dan terdapat juga beberapa siswa yang tidak berani mengemukakan pendapat. Dari fenomena tersebut timbulah permasalahan yang harus diteliti, yakni bagaimana tanggapan siswa terhadap pelaksanaan model pengajaran advokasi pada siswa? Bagaimana motivasi belajar siswa pada mata pelajaran fiqih? Bagaimana hubungan model pengajaran advokasi terhadap motivasi belajar siswa pada mata pelajaran fiqih?. Penelitian ini bertujuan untuk mengetahui: tanggapan siswa terhadap model pengajaran advokasi hubungannya dnegan motivasi belajar siswa pada mata pelajaran fiqih. Metode yang digunakan pada penelitian ini adalah metode deskriptif, karena metode ini dipandang cocok untuk penelitian ini. Metode deskriptif diarahkan untuk memecahkan masalah dengan cara memaparkan atau menggambarkan hasil penelitian. Teknik yang digunakan untuk mengumpulkan data adalah: angket, tes, observasi, wawancara, studi dokumentasi. Hasil penelitian diketahui tanggapan siswa terhadap penerapan model pengajaran advokasi menunjukan kategori tinggi, yaitu sebesar 3,74 yang berada pada interval 3,40-4,19 dan motivasi belajar siswa pada mata pelajaran Fiqih sebesar 3,94 menunjukan kategori tinggi, yang berada pada interval 3,40-4,19. Adapun analisis korelasi mengenai kedua variable sebesar 0,05 dan termasuk rendah, karena berada pada interval 0,00-0,19, Sedangkan signifikansi korelasinya diperoleh $t_{\text {hitung }}(0,2651)<t_{\text {tabel }}(1,70)$. Hal ini berarti menunjukan tidak ada hubungan yang signifikan antara keduanya. Adapun determinasi variabel X terhadap Y sebesar $5 \%$. Hal ini menunjukan bahwa masih terdapat $95 \%$ faktor lain yang turut berkontribusi terhadap motivasi belajar siswa.
\end{abstract}

Kata Kunci : Advokasi, Fiqih, Motivasi.

\begin{abstract}
This study originated from the phenomenon that emerged in MA YKDC Sumedang, namely the emergence of the gap between student responses to the advocacy teaching model with learning motivation in the subject of Fiqh. There are still $70 \%$ or 30 students who are not enthusiastic about learning as seen from their unenthusiastic, indifferent attitude and there are also some students who do not dare express their opinions. From this phenomenon arises a problem that must be examined, namely how students respond to the implementation of advocacy teaching models to students? What is the motivation for student learning in jurisprudence subjects? How does the advocacy teaching model relate to student motivation on fiqh subjects?. This study aims to determine: student responses to advocacy teaching models in relation to student learning motivation in fiqh subjects. The method used in this research is
\end{abstract}


descriptive method, because this method is considered suitable for this research. Descriptive method is directed to solve problems by describing or describing the results of research. The techniques used to collect data are: questionnaire, test, observation, interview, documentation study. The results of the study revealed that students' responses to the application of the advocacy teaching model showed a high category, namely 3.74 in the 3.40-4.19 interval and student learning motivation in the Fiqh subjects of 3.94 showed a high category, which was in the interval 3.40-4.19. The correlation analysis of the two variables is 0.05 and is low, because it is in the interval $0.00-0.19$, while the significance of the correlation is obtained $t$ count $(0.2651)<\mathrm{t}$ table $(1.70)$. This means that there is no significant relationship between the two. The determination of the variable $\mathrm{X}$ to $\mathrm{Y}$ by $5 \%$. This shows that there are still $95 \%$ of other factors that contribute to student motivation.

Keywords: advocacy, fiqih, motivation

\section{PENDAHULUAN}

Berdasarkan studi pendahuluan (observasi awal) pada siswa-siswa kelas XI MA YKDC Sumedang, diperoleh fenomena bahwa guru yang mengajar telah berusaha mempersiapkan kegiatan pembelajaran dengan semaksimal mungkin, mulai dari menyusun rencana pelaksanaan pembelajaran, memilih metode dan strategi yang tepat termasuk dalam pemberian pembelajaran menggunakan model pengajaran advokasi pada siswa. Guru menjelaskan bahwa tanggapan siswa terhadap penerapan model pengajaran advokaksi di sekolah positif, yang didasarkan adanya perasaan senang, perhatian besar, bahkan turut serta dalam aktivitas belajar. Akan tetapi, positifnya tanggapan siswa terhadap penerapan model pengajaran advokasi di sekolah, tidak diikuti dengan motivasi belajar siswa dalam mata pelajaran Fiqih. Hal ini terlihat, masih terdapat $70 \%$ siswa yang tidak antusias, acuh tak acuh dan terdapat juga beberapa siswa yang tidak berani mengemukakan pendapat.

Fenomena di atas, menunjukan adanya kesenjangan antara tanggapan dengan motivasi belajar siswa, sebab secara teoritis bahwa tanggapan memiliki peranan penting juga berpengaruh besar terhadap suatu kondisi dalam menumbuhkan motivasi dalam belajar siswa. Namun dalam realitasnya, ternyata motivasi belajar siswa dalam mata pelajaran Fiqih rendah, sehingga timbul pertanyaan bagaimana sebenarnya tanggapan siswa terhadap penerapan model pengajaran advokasi dalam pembelajaran? Bagaimana motivasi belajar siswa terhadap mata pelajaran Fiqih? Dan bagaimana hubungan model pengajaran advokasi terhadap motivasi belajar siswa? Untuk menjawab permasalahan tersebut, lebih jauh lagi akan diteliti dalam sebuah penelitian yang berjudul "TANGGAPAN SISWA TERHADAP MODEL PENGAJARAN ADVOKASI HUBUNGANNYA DENGAN MOTIVASI BELAJAR MEREKA PADA MATA PELAJARAN FIQIH (Penelitian Pada Siswa Kelas XI MA YKDC Sumedang)". 


\section{PEMBAHASAN}

Sudah merupakan tabiat manusia untuk hidup bermasyarakat, bergaul serta berkomunikasi. Alat untuk bermasyarakat, bergaul dan berkomunikasi ialah bahasa, yang disalurkan melalui media lisan dan tulisan. Awalnya pembicaraan lisan hanya digunakan untuk kepentingan hidup sehari-hari saja, namun selanjutnya pembicaraan lisan juga digunakan untuk membahas suatu masalah. Ketika suatu pembahasan masalah berlangsung, bicara dan menulis tidak hanya asal-asalan, melainkan perlu dilahirkan dari pemikiran yang jelas dan berdasarkan fakta yang akurat. Hal tersebut disimbolkan melalui kata-kata yang tepat, kalimat yang selaras, alur pikir yang sistematis dan logis, serta didasarkan pada argumentasi dan alasan pendukung yang kuat ${ }^{1}$. Tanggapan siswa terhadap interaksi belajar mengajar yang sedang berlangsung dapat berkembang dalam tiga kemungkinan yaitu menerima, acuh tak acuh dan menolak ${ }^{2}$. Berdasarkan uraian tersebut menunjukan bahwa indikator tanggapan terdiri dari tanggapan yang positif kecenderungan tindakannya adalah menerima, mengakui, memperbaiki, dan melaksanakan suatu objek, sedangkan tanggapan siswa yang negatif kecenderungan tindakannya menolak, tidak mengakui, tidak memperbaiki dan tidak melaksanakan objek tertentu.

Model adalah gambaran suatu sistem yang terdiri atas bagian-bagian yang berkaitan satu sama lain secara fungsional. Model memerlukan mekanisme kerja yang baku yang sebagian besar langkah-langkahnya harus diikuti. Pengajaran adalah suatu proses saling mempengaruhi antara guru dan siswa. Di antara keduanya terdapat hubungan atau komunikasi interaksi. Guru mengajar di satu pihak dan siswa belajar di lain pihak. Keduanya menunjukan aktivitas yang seimbang hanya berbeda peranannya saja. Advokasi berarti pembelaan, akan tetapi istilah advokasi jika kaitannya dengan kegiatan pembelajaran diidentikkan pembelaan suatu regu debat atas lawan debatnya. Fiqih adalah ilmu tentang hukum-hukum syar'i yang bersifat amaliyah yang digali dan ditemukan dari dalil-dali yang tafsili ${ }^{3}$. Fiqih adalah suatu ilmu yang mempelajari bermacam-macam syariat atau hukum Islam dan berbagai macam aturan hidup bagi manusia, baik yang bersifat individu maupun yang berbentuk masyarakat sosial $^{4}$. Dengan demikian dapat disimpulkan, yang dimaksud dengan model pengajaran advokasi ialah sebuah metode pembelajaran yang mengajak siswa aktif di kelas dan mengembangkan keterampilan berbicara menghadapi lawan bicara serta mendapat

\footnotetext{
${ }^{1}$ Nanih Machendrawaty dan Aep Kusnawan, Teknik Debat Dalam Islam (Bandung: Pustaka Setia, 2003), 28.

${ }^{2}$ Sardiman A.M, Interaksi dan Motivasi Belajar Mengajar (Jakarta: Raja Grafindo Persada, 2008), 218.

${ }^{3}$ Amir Syarifuddin, Ushul Fiqh (Jakarta: Kencana, 2008), 3.

${ }^{4}$ Hasbi Ash Shiddeqy dalam Nazar Bakry, Fiqh dan Ushul Fiqh. (Jakarta: PT. Raja Grafindo Persada, 2003), 7.
} 
pendampingan dari guru, atau dengan kata lain model pengajaran advokasi sering disebut metode debat. Sedangkan motivasi belajar adalah dorongan yang mengakibatkan perubahan dalam diri individu sebagai hasil dari aktitas dalam belajar.

Sehubungan dengan hal itu, pengajaran model advokasi menempatkan perannya dalam memberikan kerangka-kerangka, agar setiap kata dan kalimat serta konsep dan argumentasi yang dibuat seseorang memiliki landasan konseptual logis yang kuat, sehingga memiliki kekuatan dari setiap uji argumentasi yang diajukan. Hal ini sesuai dengan apa yang diungkapkan Oemar Hamalik (2009:229) bahwa melalui pendekatan instruksional belajar advokasi mengembangkan keterampilan-keterampilan dalam logika, pemecahan masalah, berfikir kritis, serta komunikasi lisan dan tulisan. ${ }^{5}$

Sebagai variabel $\mathbf{X}$ pengajaran model advokasi (debat) mempunyai beberapa indikator, di antaranya adalah: (1) Menyusun topik (2) Menyusun argumen (3) Menyusun sanggahan (4) peraturan perdebatan (5) Perdebatan ${ }^{6}$.(Utomo Dananjaya, 2012: 86-88).

Apabila indikator tersebut dilaksanakan oleh guru dalam pengajaran model advokasi maka akan timbul rangsangan yang positif untuk motivasi belajar mereka. Para ahli pendidikan sependapat bahwa motivasi mempunyai arti penting dalam mempengaruhi belajar siswa. Karena itu motivasi adalah suatu usaha yang disadari untuk mempengaruhi tingkah laku seseorang agar ia tergerak hatinya untuk bertindak melakukan sesuatu sehingga mencapai hasil atau tujuan tertentu (M. Ngalim Purwanto, 2000: 71) ${ }^{7}$. Apabila diarahkan pada belajar, maka motivasi belajar merupakan aspek mental yang memiliki daya dorong bagi seseorang untuk belajar.

Dari definisi ini jelas betapa pentingnya peran motivasi dalam pembelajaran karena dengan adanya motivasi siswa tidak hanya akan belajar dengan giat tetapi juga menikmatinya. Tinggi rendahnya motivasi seseorang tidak terlepas dari adanya pengaruh lingkungan sekitar. Oleh karenanya dalam pembelajaran dikenal dua jenis motivasi dilihat dari sumber datangnya motivasi tersebut yaitu :

a. Motivasi instrinsik, yaitu motivasi untuk belajar yang berasal dari dalam diri siswa itu sendiri. Motivasi instrisik ini diantaranya ditimbulkan oleh faktor-faktor yang muncul dari pribadi siswa itu sendiri terutama kesadaran akan manfaat materi pelajaran bagi siswa itu sendiri.

b. Motivasi ekstrinsik, yaitu motivasi untuk belajar yang berasal dari luar diri siswa itu sendiri. Motivasi ekstrinsik ini diantaranya ditimbulkan oleh faktor-faktor yang muncul

\footnotetext{
${ }^{5}$ Oemar Hamalik, Proses Belajar dan Pembelajaran (Jakarta: PT. Bumi Aksara, 2009), 229.

${ }^{6}$ Utomo Dananjaya, Media Pembelajaran Aktif (Bandung: Nuansa, 2012), 86-88.

${ }^{7}$ M. Ngalim Purwanto, Psikologi Pendidikan (Bandung: PT Remaja Rosdakarya, 2000), 71.
} 
dari luar pribadi siswa itu sendiri termasuk dari guru. Faktor-faktor tersebut bisa positif bisa juga negatif ${ }^{8}$.

Indikator motivasi di antaranya: (1) Durasinya kegiatan (2) Frekuensinya kegiatan (3) Persistensinya (ketetapan dan kelekatannya) (4) Ketabahan, keuletan, dan kemampuannya dalam mengahadapi rintangan dan kesulitan untuk mencapai tujuan (5) Devosi (pengabdian) dan pengorbanan (6) Tingkatan aspirasinya yang hendak dicapai dengan kegiatan yang dilakukan (7) Tingkatan kualifikasi prestasi atau produk atau output yang dicapai dari kegiatannya (8) Arah sikapnya terhadap sasaran kegiatan (like or dislike; positif atau negatif) 9 .

Berdasarkan rumusan di atas, dapat dikatakan motivasi muncul karena adanya hubungan penggunaan model pembelajaran. Secara teoritik, munculnya motivasi pada diri seseorang ada keterkaitannya dengan penggunaan model pembelajaran yang digunakan. Salah satunya model pengajaran advokasi sebagai metode yang dianggap relevan sebagai dasar bagi tumbuh dan berkembangnya motivasi belajar siswa pada bidang studi Fiqih.

Pokok-pokok pemikiran di atas, secara skematis dapat digambarkan sebagai berikut :

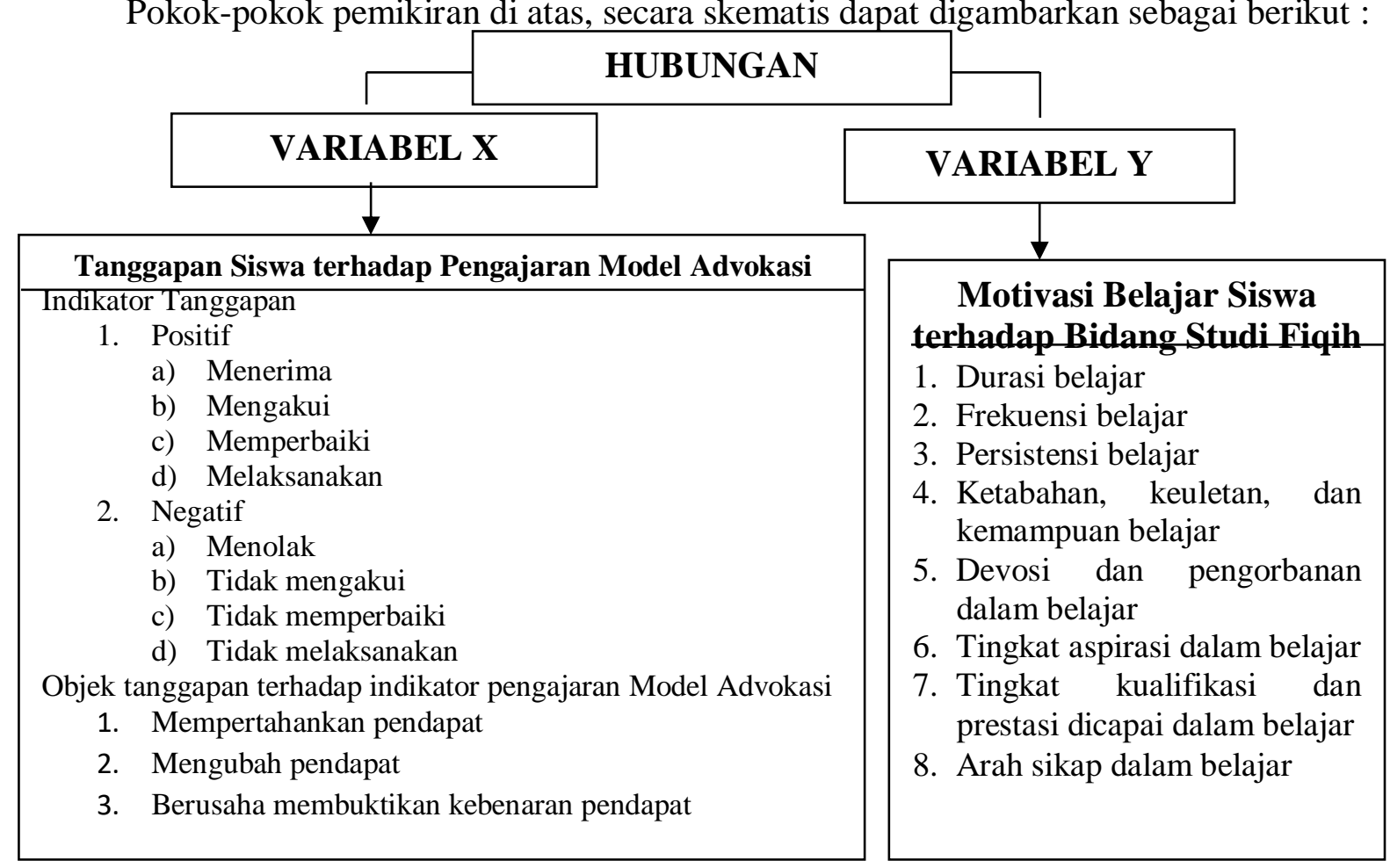

\section{Prosedur Analisis Data}

Menanggapi dua variabel yang diteliti, memberikan kerangka acuan teoritik bahwa kadar motivasi belajar siswa ada ketergantungan pada kondisi dan situasi lingkungan tempat siswa belajar, khususnya hubungan pengajaran model advokasi dalam pembelajaran. Oleh

\footnotetext{
${ }^{8}$ Abdorrakhman Gintings, Esensi Praktis; Belajar dan Pembelajaran (Bandung: Humaniora, 2010), 88.

${ }^{9}$ Abin Syamsudin Makmun, Psikologi Kependidikan. (Bandung: PT Remaja Rosdakarya, 2009), 40.
} 
karena itu, beranjak dari asumsi teoritik tersebut dengan berdasarkan pada kenyataan yang melibatkan siswa/i kelas XI MA YKDC Sumedang, penilitian akan bertolak dari hipotesis, "terdapat hububgan antara terhadap pengajaran model advokasi dengan motivasi belajar siswa pada bidang studi fiqih.

Adapun hipotesis ini penulis gunakan sebagai hipotesis kerja (Ha) dan hipotesis nihil (Ho) yang berbunyi :

Ha : Terdapat hubungan antara pengajaran model advokasi dengan motivasi belajar siswa pada bidang studi fiqih

Ho : Tidak ada hubungan antara pengajaran model advokasi dengan motivasi belajar siswa pada bidang studi fiqih

Setelah data terkumpul, maka langkah selanjutnya adalah pengolahan data. Semua data yang diperoleh dapat dianalisis melalui tahapan-tahapan yaitu mengklasifikasikan data, sedangkan untuk mendapatkan data, mengkuantifikasikan data, menganalisis, dan menyimpulkan. Dari data yang terkumpul berupa data-data kuantitatif dianalisis dengan menggunakan analisis statistik. Adapun analisisnya dilakukan melalui dua tahap yaitu analisis parsial dan analisis korelasional.

1. Analisis Parsial

Analisis parsial adalah analisis yang digunakan untuk mendalami dua variabel yaitu variabel X (pengajaran model advokasi) dan variable $\mathrm{Y}$ (Motivasi belajar siswa). Untuk mendalami kedua variabel tersebut langkah-langkah yang dilakukan adalah sebagai berikut:

a. Analisis parsial tiap indikator untuk tiap variabel dengan menggunakan rumus:

$\begin{array}{ll}\text { Untuk variabel X dengan rumus : } & \mathrm{M}_{\mathrm{x}}=\frac{\sum f x}{N} \\ \text { Untuk vaiabel Y dengan rumus : } & \mathrm{M}_{\mathrm{x}}=\frac{\sum f y}{N}\end{array}$

Keterangan:

$\mathrm{M}_{\mathrm{x}} \quad=$ mean yang dicari

$\sum f x=$ Jumlah dari hasil perkalian antara midpoint dari masing-masing interval, dengan frekuensinya

$\mathrm{N} \quad=$ Jumlah responden $^{10}$

Menginterprestasikan nilai rata-rata yang dihasilkan dengan berdasarkan identitas terhadap skala nilai sebagai berikut: 
- Rata-rata antara $1,00-1,79$ berarti kurang sekali

- Rata-rata antara 1,80 - 2,59 berarti kurang

- Rata-rata antara 2,60 - 3,39 berarti cukup

- Rata-rata antara 3,40 - 4,19 berarti baik

- Rata-rata antara 4,20 - 5,00 berarti sangat baik. ${ }^{11}$

b. Uji Normalitas Data

Uji normalitas digunakan untuk mengetahui apakah populasi data berdistribusi normal atau tidak. Uji ini biasanya digunakan untuk mengukur data berskala ordinal, interval, ataupun rasio. Jika analisis menggunakan metode parametrik, maka persyaratan normalitas harus terpenuhi yaitu data berasal dari distribusi yang normal. Jika data tidak berdistribusi normal, atau jumlah sampel sedikit dan jenis data adalah nominal atau ordinal maka metode yang digunakan adalah statistik non parametrik. Dalam pembahasan ini alat ujinya menggunakan rumus chi kuadrat $\left(X^{2}\right)$ harga yang diperlukan untuk uji normalitas data variable $x$ dan variable $y$ dengan menggunakan taraf signifikansi 0,05. Data dinyatakan berdistribusi normal jika signifikansi lebih besar dari $5 \%$ atau 0,05 .

Setelah dilakukan pengolahan data dengan perhitungan statistik untuk lebih meyakinkan dugaan bahwa distribusi frekuensi normal alat ujinya menggunakan rumus chi kuadrat $\left(X^{2}\right)$ harga yang diperlukan untuk uji normalitas data variable $x$ dan variable $y$ dapat dilihat pada tabel dibawah ini :

Tabel 01

Deskripsi data variable $x$ dan variable $y$

\begin{tabular}{|l|c|c|}
\multicolumn{1}{|c}{} \\
\multicolumn{1}{|c|}{ Parameter } & \multicolumn{2}{c|}{ Variabel } \\
\cline { 2 - 3 } & $\boldsymbol{x}$ & $\boldsymbol{y}$ \\
\hline Skor Tertinggi & 64 & 74 \\
\hline Skor Terendah & 48 & 44 \\
\hline Jumlah Responden & 30 & 30 \\
\hline Kelas Interval & 3 & 6 \\
\hline Panjang Kelas & 56,96 & 5 \\
\hline Rata-rata (Mean) & 4,23 & 64,76 \\
\hline Standar Deviasi (Sd) & 11,13 & 80,72 \\
\hline $\begin{array}{l}\text { Chi Kuadrat Hitung } \\
\left(X_{\text {hitung }}^{2}\right)\end{array}$ & 7,81 & 7,81 \\
\hline Chi Kuadrat Tabel $\left(X_{\text {tabel }}^{2}\right)$ & 3 & 3 \\
\hline Derajat Kebebasan $(\mathrm{dk})$ & &
\end{tabular}

${ }^{11}$ Sambas Ali Muludin, Maman Abdurrahman, Analisis Korelasi, Regresi dan Jalur dalam Penelitian (Bandung: Pustaka Setia, 2009), 146. 
Dari tabel di atas berikut rumus-rumus yang dipakai oleh peneliti:

a. Mencari Nilai Rentang (R)

$\mathrm{R}=($ Data tertinggi - Data terendah $)$

b. Menentukan Banyaknya Kelas Interval (K)

$\mathrm{K}=1+3,3(\log \mathrm{n})$

c. Menentukan Panjang Kelas Interval (P)

$\mathrm{P}=\frac{R}{K}$

d. Membuat Tabel Distribusi Frekuensi

e. Menentukan Nilai Mean $(\bar{X})$

$\bar{X}=\frac{\sum f i \quad x i}{\sum f i}$

f. Menentukan Standar Deviasi (Sd)

$\mathrm{Sd}=\sqrt{\frac{\sum f_{i} x_{i}{ }^{2}-\frac{\left(\Sigma f_{i} x_{i}\right)^{2}}{\sum f_{i}}}{\sum f_{i}{ }^{-1}}}$

g. Membuat daftar distribusi frekuensi observasi dan ekspektasi

h. Menghitung nilai Chi Kuadrat

$X^{2}=\sum_{i-1}^{k} \frac{(O i-E i)^{2}}{E i}$

i. Menentukan Derajat Kebebasan (dk)

$\mathrm{dk}=\mathrm{Ki}-3$

j. Menentukan $X^{2}$ tabel dengan taraf signifikansi 5\%

Uji normalitas digunakan untuk mengetahui suatu data berdistribusi normal atau tidak.

Suatu data dikatakan normal apabila memenuhi kriteria jika $X_{\text {hitung }}^{2}<X_{\text {tabel }}^{2}$, maka data berdistribusi normal. Tetapi apabila $X_{\text {hitung }}^{2}>X_{\text {tabel }}^{2}$ maka data berdistribusi tidak normal. Dari hasil analisis data variable $x$ menunjukkan bahwa $X_{\text {hitung }}^{2}=11,13>7,81=X_{\text {tabel }}^{2}$ maka data hasil tes berdistribusi Tidak Normal dan data variable $y$ menunjukkan bahwa $X_{\text {hitung }}^{2}=$ $80,72>7,81=X_{\text {tabel }}^{2}$ maka data hasil tes berdistribusi Tidak Normal.

2. Menentukan tabel untuk mencari harga-harga yang diperlukan untuk pengujian liniaritas regresi serta analisis koefisien korelasi

Tabel 02

\begin{tabular}{|l|c|c|c|c|c|}
\hline No & $\mathrm{X}$ & $\mathrm{Y}$ & $\mathrm{X}^{2}$ & $\mathrm{Y}^{2}$ & $\mathrm{XY}$ \\
\hline 1 & 55 & 47 & 3025 & 2209 & 2585 \\
\hline
\end{tabular}




\begin{tabular}{|c|c|c|c|c|c|}
\hline 2 & 50 & 63 & 2500 & 3969 & 3150 \\
\hline 3 & 54 & 64 & 2916 & 4096 & 3456 \\
\hline 4 & 64 & 73 & 4096 & 5329 & 4672 \\
\hline 5 & 62 & 54 & 3844 & 2916 & 3348 \\
\hline 6 & 48 & 54 & 2304 & 2916 & 2592 \\
\hline 7 & 48 & 55 & 2304 & 3025 & 2640 \\
\hline 8 & 59 & 65 & 3481 & 4225 & 3835 \\
\hline 9 & 56 & 65 & 3136 & 4225 & 3640 \\
\hline 10 & 60 & 57 & 3600 & 3249 & 3420 \\
\hline 11 & 54 & 64 & 2916 & 4096 & 3456 \\
\hline 12 & 61 & 50 & 3721 & 2500 & 3035 \\
\hline 13 & 58 & 68 & 3364 & 2809 & 3944 \\
\hline 14 & 61 & 63 & 3721 & 3969 & 3843 \\
\hline 15 & 63 & 53 & 3969 & 2809 & 3339 \\
\hline 16 & 53 & 68 & 2809 & 4624 & 3604 \\
\hline 17 & 55 & 61 & 3025 & 3721 & 3355 \\
\hline 18 & 55 & 52 & 3025 & 2704 & 2860 \\
\hline 19 & 50 & 61 & 2500 & 3721 & 3050 \\
\hline 20 & 55 & 62 & 3025 & 3844 & 3410 \\
\hline 21 & 55 & 67 & 3025 & 4489 & 3685 \\
\hline 22 & 61 & 56 & 3721 & 3136 & 3416 \\
\hline 23 & 55 & 59 & 3025 & 3481 & 3245 \\
\hline 24 & 55 & 44 & 3025 & 1936 & 2420 \\
\hline 25 & 57 & 67 & 3249 & 4489 & 3819 \\
\hline 26 & 53 & 63 & 2809 & 3969 & 3339 \\
\hline 27 & 60 & 74 & 3600 & 5476 & 4440 \\
\hline
\end{tabular}




\begin{tabular}{|l|c|c|c|l|l|}
\hline 28 & 59 & 52 & 3481 & 2704 & 3068 \\
\hline 29 & 60 & 49 & 3600 & 2401 & 2940 \\
\hline 30 & 60 & 69 & 3600 & 4761 & 4140 \\
\hline & $\mathbf{1 6 9 6}$ & $\mathbf{1 7 9 9}$ & $\mathbf{9 6 4 1 6}$ & $\mathbf{1 0 7 7 9 8}$ & $\mathbf{1 0 1 7 4 6}$ \\
\hline
\end{tabular}

Dari tabel di atas diketahui

$$
\begin{aligned}
& \mathrm{Xi}=1696 \quad \mathrm{Xi}^{2}=1799 \quad \mathrm{XiYi}=101746 \\
& \mathrm{Yi}=1799 \quad \mathrm{Yi}^{2}=96416
\end{aligned}
$$

1. Menetapkan rumus persamaan regresi linier dengan rumus:

$$
\begin{aligned}
\hat{Y} & =a+b x \\
a & =\frac{\left(\sum Y i\right)\left(\sum X i^{2}\right)-\left(\sum X i\right)\left(\sum X i Y i\right)}{n\left(\sum X i^{2}\right)-\left(\sum X i\right)^{2}} \\
& =\frac{(1799)(96416)-(1696)(101746)}{30(96416)-(1696)^{2}} \\
& =\frac{173452384-172561216}{2892480-2876416} \\
& =\frac{891168}{16064} \\
& =55,47 \text { dibulatkan menjadi 55 } \\
a & =55,47 \\
b & =\frac{n \sum X i Y i-\left(\sum X i\right)\left(\sum Y i\right)}{n\left(\sum X i^{2}\right)-\left(\sum X i\right)^{2}} \\
& =\frac{1276}{16064} \\
& =\frac{30(101746)-1696(1799)}{30(96416)-(1696)^{2}} \\
& \frac{3052380-3051104}{2892480-2875416} \\
&
\end{aligned}
$$




$$
b=0,07
$$

2. Menentukan linieritas regresi dengan langkah-langkah sebagai berikut

a. Menghitung jumlah kuadrat regresi a (JKa) dengan rumus:

$$
\begin{aligned}
J K a & =\frac{\left(\sum Y\right)^{2}}{N} \\
& =\frac{1799^{2}}{30} \\
& =\frac{3236401}{30} \\
J K a & =107880,03
\end{aligned}
$$

b. Menghitung jumlah kuadrat regresi b terhadap a dengan rumus:

$$
\begin{aligned}
J K_{b / a} & =b\left[\sum X Y-\frac{\left(\sum X\right)\left(\sum Y\right)}{N}\right] \\
& =0,07\left[101746-\frac{(1696) \times(1799)}{30}\right] \\
& =0,07\left[101746-\frac{3051104}{30}\right] \\
& =0,07[101746-101703,46] \\
& =0,07[42,53] \\
J K_{b / a} & =2,97
\end{aligned}
$$

c. Menghitung jumlah kuadrat residu dengan rumus:

$$
\begin{aligned}
J K_{\text {res }} & =\sum Y^{2}-J K a-J K_{b / a} \\
& =107798-107880,03-2,97 \\
J K_{\text {res }} & =-85
\end{aligned}
$$

d. Menghitung jumlah kuadrat kekeliruan dengan rumus:

$$
J K_{k k}=\sum\left[Y^{2}-\frac{(Y)^{2}}{n}\right]
$$

Untuk menghitung rumus di atas diperlukan tabel sebagai berikut:

$$
\text { Tabel } 03
$$

\section{Daftar Pasangan Variabel X dan Y}

\begin{tabular}{|c|c|c|c|c|}
\hline N0 & Xi & Kelas & Ni & Yi \\
\hline 1 & $\mathbf{6 4}$ & $\mathbf{1}$ & $\mathbf{1}$ & $\mathbf{7 4}$ \\
\hline
\end{tabular}




\begin{tabular}{|c|c|c|c|c|}
\hline 2 & 63 & 2 & 1 & 73 \\
\hline 3 & 62 & 3 & 1 & 69 \\
\hline 4 & 61 & \multirow{3}{*}{4} & \multirow{3}{*}{3} & 68 \\
\hline 5 & 61 & & & 68 \\
\hline 6 & 61 & & & 67 \\
\hline 7 & 60 & \multirow{4}{*}{5} & \multirow[t]{4}{*}{4} & 66 \\
\hline 8 & 60 & & & 65 \\
\hline 9 & 60 & & & 65 \\
\hline 10 & 60 & & & 64 \\
\hline 11 & 59 & \multirow[t]{2}{*}{6} & \multirow[t]{2}{*}{2} & 64 \\
\hline 12 & 59 & & & 63 \\
\hline 13 & 58 & 7 & 1 & 63 \\
\hline 14 & 57 & 8 & 1 & 63 \\
\hline 15 & 56 & 9 & 1 & 62 \\
\hline 16 & 55 & \multirow{7}{*}{10} & \multirow[t]{7}{*}{7} & 61 \\
\hline 17 & 55 & & & 61 \\
\hline 18 & 55 & & & 59 \\
\hline 19 & 55 & & & 57 \\
\hline 20 & 55 & & & 56 \\
\hline 21 & 55 & & & 55 \\
\hline 22 & 55 & & & 54 \\
\hline 23 & 54 & \multirow[t]{2}{*}{11} & \multirow[t]{2}{*}{2} & 54 \\
\hline 24 & 54 & & & 53 \\
\hline 25 & 53 & \multirow[t]{2}{*}{12} & \multirow[t]{2}{*}{2} & 52 \\
\hline 26 & 53 & & & 52 \\
\hline 27 & 50 & \multirow[t]{2}{*}{13} & \multirow[t]{2}{*}{2} & 50 \\
\hline 28 & 50 & & & 49 \\
\hline 29 & 48 & \multirow[t]{2}{*}{14} & \multirow[t]{2}{*}{2} & 47 \\
\hline 30 & 48 & & & 47 \\
\hline JUMLAH & 1696 & & & 1799 \\
\hline
\end{tabular}

$$
J K_{k k}=
$$

$$
\begin{aligned}
& {\left[68^{2}+68^{2}+67^{2}-\frac{(58+68+67)^{2}}{3}\right]+\left[65^{2}+65+64^{2}+64^{2}-\frac{(65+65+64+64)^{2}}{3}\right]+} \\
& {\left[64^{2}+63^{2}-\frac{(64+63)^{2}}{2}\right]+}
\end{aligned}
$$$$
\left[61^{2}+61^{2}+59^{2}+57^{2}+56^{2}+55+54^{2}-\frac{(61+61+59+57+56+55+54)^{2}}{7}\right]+
$$$$
\left[52^{2}+52^{2}-\frac{(52+52)^{2}}{2}\right]+
$$$$
\left[47^{2}+47^{2}-\frac{(47+47)^{2}}{2}\right]+
$$ 


$$
\begin{aligned}
& =(13737-1373,33)+(16642-16641)+(8194-8064,5)+ \\
& (23999-23201,28)+(5408-5408)+(4418-4418) \\
& =0,67+1+129+797,89+0+0 \\
& \quad J K_{k k}=928,89
\end{aligned}
$$

1) Menghitung derajat kebebasan kekeliruan dengan rumus:

$$
\begin{aligned}
d b_{k k}= & n-k \\
& =30-15 \\
& =15
\end{aligned}
$$

2) Menghitung derajat kebebasan ketidak cocokan dengan rumus:

$$
\begin{aligned}
d b_{t c} & =k-2 \\
& =15-2 \\
& =13
\end{aligned}
$$

3) Menghitung jumlah kuadrat ketidak cocokan dengan rumus:

$$
\begin{aligned}
J K_{t c} & =J K_{r e s}-J K_{k k} \\
& =126390,19-928,89 \\
& =125461,3
\end{aligned}
$$

4) Menghitung rata-rata kuadrat kekeliruan dengan rumus:

$$
\begin{aligned}
& R K_{k k}=J K_{k k}: d b_{k k} \\
& =928,89: 15 \\
& =61,92
\end{aligned}
$$

5) Menghitung rata-rata kuadrat ketidak cocokan dengan rumus:

$$
\begin{aligned}
R K_{t c} & =J K_{t c}: d b_{t c} \\
& =125461,3: 13 \\
& =9650,89
\end{aligned}
$$

6) Menghitung nilai $F$ ketidak cocokan dengan rumus:

$$
\begin{aligned}
& F_{t c}=R K_{t c}: R K_{k k} \\
& =9650,86: 61,92 \\
& =155,86
\end{aligned}
$$

7) Menentukan nilai $\mathrm{F}$ tabel pada taraf signifikansi $5 \%$

Jika Ftc $<$ F table maka regresi linier

Jika Ftc > Ftabel maka regresi tidak linier

8) Pemeriksaan Linieritas regresi 


$$
\begin{aligned}
\mathrm{F} \text { tablel }= & F_{\text {tabel }}=(1-a)\left(d b_{t c} / d b_{k k}\right) \\
= & (1-0,05)(13 / 15) \\
= & (0,95)(12 / 6) \\
= & 2,413
\end{aligned}
$$

Berdasarkan hasil perhitungan diatas, ternyata $\mathrm{F}$ hitung $=155,86$ lebih besar dari $\mathrm{F}$ table yaitu $=2,413$ Dengan demikian, maka persamaan regresi yang diperoleh adalah regresi linear.

3. Menghitung nilai koefisien korelasi

Analisis Korelasi antara Variabel X dan Variabel Y

Setelah mengolah data kedua variabel di atas, maka diketahui bahwa variabel $\mathrm{X}$ dan $\mathrm{Y}$ berdistribusi tidak normal dan regresinya linear. Dengan demikian karena variabelnya tidak berdistribusi normal, maka pengujian korelasi dilakukan dengan statistic non parametik yaitu teknik Rank sebagai berikut:

Tabel 04

\section{Perhitungan Koefesiensi Korelasi denagn rumus Rank}

\begin{tabular}{|c|c|c|c|c|c|c|}
\hline $\mathbf{N O}$ & $\mathbf{X i}$ & $\mathbf{Y i}$ & $\mathbf{R x}$ & $\mathbf{R y}$ & $\mathbf{b i}$ & $\mathbf{B 2}$ \\
\hline $\mathbf{1}$ & 55 & 47 & $\mathbf{1 9}$ & $\mathbf{2 9 , 5}$ & $\mathbf{- 1 0 , 5}$ & $\mathbf{1 1 0 , 2 5}$ \\
\hline $\mathbf{2}$ & 50 & 63 & $\mathbf{2 7 , 5}$ & $\mathbf{1 3}$ & $\mathbf{1 4 , 5}$ & $\mathbf{2 1 0 , 2 5}$ \\
\hline $\mathbf{3}$ & 54 & 64 & $\mathbf{2 3 , 5}$ & $\mathbf{1 0 , 5}$ & $\mathbf{1 3}$ & $\mathbf{1 6 9}$ \\
\hline $\mathbf{4}$ & 64 & 73 & $\mathbf{1}$ & $\mathbf{2}$ & $\mathbf{- 1}$ & $\mathbf{1}$ \\
\hline $\mathbf{5}$ & 62 & 54 & $\mathbf{3}$ & $\mathbf{2 2 , 5}$ & $\mathbf{- 1 9 , 5}$ & $\mathbf{3 8 0 , 2 5}$ \\
\hline $\mathbf{6}$ & 48 & 54 & $\mathbf{2 9 , 5}$ & $\mathbf{2 2 , 5}$ & $\mathbf{7}$ & $\mathbf{4 9}$ \\
\hline $\mathbf{7}$ & 48 & 55 & $\mathbf{2 9 , 5}$ & $\mathbf{2 0}$ & $\mathbf{9 , 5}$ & $\mathbf{9 0 , 2 5}$ \\
\hline $\mathbf{8}$ & 59 & 65 & $\mathbf{1 1 , 5}$ & $\mathbf{8 , 5}$ & $\mathbf{3}$ & $\mathbf{9}$ \\
\hline $\mathbf{9}$ & 56 & 65 & $\mathbf{1 4}$ & $\mathbf{8 , 5}$ & $\mathbf{5 , 5}$ & $\mathbf{3 0 , 2 5}$ \\
\hline $\mathbf{1 0}$ & 60 & 57 & $\mathbf{8 , 5}$ & $\mathbf{1 8}$ & $\mathbf{- 9 , 5}$ & $\mathbf{9 0 , 2 5}$ \\
\hline $\mathbf{1 1}$ & 54 & 64 & $\mathbf{2 5 , 5}$ & $\mathbf{1 0 , 5}$ & $\mathbf{1 5}$ & $\mathbf{2 2 5}$ \\
\hline $\mathbf{1 2}$ & 61 & 50 & $\mathbf{5}$ & $\mathbf{2 6}$ & $\mathbf{- 2 1}$ & $\mathbf{4 4 1}$ \\
\hline
\end{tabular}




\begin{tabular}{|c|c|c|c|c|c|c|}
\hline 13 & 58 & 68 & 12 & 4,5 & 7,5 & 56,25 \\
\hline 14 & 61 & 63 & 5 & 13 & -8 & 64 \\
\hline 15 & 63 & 53 & 2 & 23 & -21 & 441 \\
\hline 16 & 53 & 68 & 25,5 & 4,5 & 21 & 441 \\
\hline 17 & 55 & 61 & 19 & 16,5 & 2,5 & 6,25 \\
\hline 18 & 55 & 52 & 19 & 25,5 & $-6,5$ & 42,25 \\
\hline 19 & 50 & 61 & 27,5 & 16,5 & 11 & 121 \\
\hline 20 & 55 & 62 & 19 & 14 & 5 & 25 \\
\hline 21 & 55 & 67 & 19 & 6,5 & 12,5 & 156,25 \\
\hline 22 & 61 & 56 & 5 & 19 & -14 & 196 \\
\hline 23 & 55 & 59 & 19 & 17 & 2 & 4 \\
\hline 24 & 55 & 44 & 19 & 29,5 & $-10,5$ & 110,25 \\
\hline 25 & 57 & 67 & 13 & 6,5 & 6,5 & 42,25 \\
\hline 26 & 53 & 63 & 25,5 & 13 & 12,5 & 156,25 \\
\hline 27 & 60 & 74 & 8,5 & 1 & 7,5 & 56,25 \\
\hline 28 & 59 & 52 & 11,5 & 25,5 & -14 & 196 \\
\hline 29 & 60 & 49 & 8,5 & 27 & $-18,5$ & 342,25 \\
\hline \multirow[t]{2}{*}{30} & 60 & 69 & 8,5 & 3 & 5,5 & 30,25 \\
\hline & & & & & & 4292 \\
\hline
\end{tabular}

TABEL 05

Daftar Pasangan Variabel X dan Variabel Y untuk Korelasi

\begin{tabular}{|c|c|c|c|c|c|c|}
\hline No & $\mathrm{X}$ & $\mathrm{Y}$ & $\boldsymbol{r}_{\boldsymbol{x}}$ & $\boldsymbol{r}_{\boldsymbol{y}}$ & $\mathrm{D}\left(\mathbf{r}_{\mathrm{x}-} \mathbf{r}_{\mathbf{y}}\right)$ & $\mathrm{D}^{2}\left(\mathbf{r}_{\mathrm{x}-} \mathbf{r}_{\mathbf{y}}\right)^{2}$ \\
\hline 1 & 55 & $\mathbf{4 7}$ & $\mathbf{1 9}$ & $\mathbf{2 9 , 5}$ & $\mathbf{- 1 0 , 5}$ & $\mathbf{1 1 0 , 2 5}$ \\
\hline 2 & 50 & $\mathbf{6 3}$ & $\mathbf{2 7 , 5}$ & $\mathbf{1 3}$ & $\mathbf{1 4 , 5}$ & $\mathbf{2 1 0 , 2 5}$ \\
\hline 3 & 54 & $\mathbf{6 4}$ & $\mathbf{2 3 , 5}$ & $\mathbf{1 0 , 5}$ & $\mathbf{1 3}$ & $\mathbf{1 6 9}$ \\
\hline
\end{tabular}




\begin{tabular}{|c|c|c|c|c|c|c|}
\hline 4 & 64 & 73 & 1 & 2 & -1 & 1 \\
\hline 5 & 62 & 54 & 3 & 22,5 & $-19,5$ & 380,25 \\
\hline 6 & 48 & 54 & 29,5 & 22,5 & 7 & 49 \\
\hline 7 & 48 & 55 & 29,5 & 20 & 9,5 & 90,25 \\
\hline 8 & 59 & 65 & 11,5 & 8,5 & 3 & 9 \\
\hline 9 & 56 & 65 & 14 & 8,5 & 5,5 & 30,25 \\
\hline 10 & 60 & 57 & 8,5 & 18 & $-9,5$ & 90,25 \\
\hline 11 & 54 & 64 & 25,5 & 10,5 & 15 & 225 \\
\hline 12 & 61 & 50 & 5 & 26 & -21 & 441 \\
\hline 13 & 58 & 68 & 12 & 4,5 & 7,5 & 56,25 \\
\hline 14 & 61 & 63 & 5 & 13 & -8 & 64 \\
\hline 15 & 63 & 53 & 2 & 23 & -21 & 441 \\
\hline 16 & 53 & 68 & 25,5 & 4,5 & 21 & 441 \\
\hline 17 & 55 & 61 & 19 & 16,5 & 2,5 & 6,25 \\
\hline 18 & 55 & 52 & 19 & 25,5 & $-6,5$ & 42,25 \\
\hline 19 & 50 & 61 & 27,5 & 16,5 & 11 & 121 \\
\hline 20 & 55 & 62 & 19 & 14 & 5 & 25 \\
\hline 21 & 55 & 67 & 19 & 6,5 & 12,5 & 156,25 \\
\hline 22 & 61 & 56 & 5 & 19 & -14 & 196 \\
\hline 23 & 55 & 59 & 19 & 17 & 2 & 4 \\
\hline 24 & 55 & 44 & 19 & 29,5 & $-10,5$ & 110,25 \\
\hline 25 & 57 & 67 & 13 & 6,5 & 6,5 & 42,25 \\
\hline 26 & 53 & 63 & 25,5 & 13 & 12,5 & 156,25 \\
\hline 27 & 60 & 74 & 8,5 & 1 & 7,5 & 56,25 \\
\hline 28 & 59 & 52 & 11,5 & 25,5 & -14 & 196 \\
\hline 29 & 60 & 49 & 8,5 & 27 & $-18,5$ & 342,25 \\
\hline
\end{tabular}




\begin{tabular}{|c|c|c|c|c|c|c|}
\hline 30 & 60 & 69 & $\mathbf{8 , 5}$ & 3 & $\mathbf{5 , 5}$ & $\mathbf{3 0 , 2 5}$ \\
\hline & $\mathbf{1 6 9 6}$ & $\mathbf{1 7 9 9}$ & & & & $\mathbf{4 2 9 2}$ \\
\hline
\end{tabular}

$$
\begin{aligned}
\mathrm{RH}_{\text {oxy }} & =1-\frac{6 \cdot \sum \mathrm{D}^{2}}{\mathrm{n}\left(\mathrm{n}^{2}-1\right)} \\
& =1-\frac{6 \cdot 4292}{30\left(30^{2}-1\right)} \\
& =1-\frac{25752}{30(899)} \\
& =1-\frac{25752}{26970} \\
& =1-0,95=0,05
\end{aligned}
$$

3. Menentukan uji signifikansi korelasi atau menguji hipotesis dengan langkah-langkah sebagai berikut:

a) Menentukan t hitung, dengan rumus:

$$
\begin{aligned}
t_{\text {hitung }} & =\frac{r \sqrt{n-2}}{\sqrt{1-r^{2}}} \\
& =\frac{0,05 \sqrt{30-2}}{\sqrt{1-0,05^{2}}} \\
& =\frac{0,05.5,29}{\sqrt{1-0,0025}} \\
& =\frac{0,2645}{0,9975} \\
& =0,2651
\end{aligned}
$$

b) Menentukan derajat kebebasan, dengan rumus:

$$
\begin{aligned}
d b & =n-2 \\
& =30-2=28
\end{aligned}
$$

c) Menentukan nilai t tabel

Menentukan nilai t tabel dengan taraf signifikansi $5 \%$ dengan $\mathrm{db}=28$, dengan rumus:

$$
\begin{aligned}
t_{\text {tabel }} & =(1-a)(d b) \\
& =(1-0,05)(28)
\end{aligned}
$$




$$
\begin{aligned}
& =(0,95)(28) \\
& =1,70
\end{aligned}
$$

Berdasarkan hubungan di atas, diketahui bahwa harga t hitung, 0,2651 lebih kecil dari pada $t$ tabel 1,70. Karena $\mathrm{t}$ hitung $<\mathrm{t}$ tabel, maka hipotesis $\left(H_{o}\right)$ diterima. Dalam arti tidak ada hubungan antara tanggapan siswa terhadap penerapan model pengajaran advokasi hubungannya dengan motivasi belajar mereka pada mata pelajaran fiqih

\section{KESIMPULAN}

Realitas hubungan antara tanggapan siswa terhadap penerapan model pengajaran advokasi dengan motivasi belajar siswa pada mata pelajaran Fiqih ditunjukan dengan hasil perhitungan koefisien korelasi antara variabel $\mathrm{X}$ dan $\mathrm{Y}$ yang mencapai nilai sebesar 0,05. Harga koefisien korelasi tersebut berada pada skala korelasi 0,00-0,19 yang menunjukan bahwa korelasi rendah. Sedangkan determinasi variabel X terhadap Y adalah sebesar 5\%. Hal ini menggambarkan masih ada faktor lain sebesar 95,00\% yang berkonstribusi terhadap motivasi belajar siswa pada mata pelajaran Fiqih. Hasil uji signifikansi koefisien korelasi diperoleh nilai $t_{\text {hitung }}<\mathrm{t}_{\text {tabel }}$ yaitu $0,2651<1,70$ maka hipotesis nol $\left(\mathrm{H}_{\mathrm{O}}\right)$ yang menyatakan tidak ada hubungan yang signifikan antara tanggapan siswa terhadap model pengajaran advokasi hubungannya dengan motivasi belajar mereka pada mata pelajaran fiqih.

Setelah mengetahui hasil penelitian mengenai tanggapan siswa terhadap model pengajaran advokasi hubungannya dengan motivasi belajar mereka pada mata pelajaran fiqih, maka terdapat beberapa saran sebagai berikut:

1. Dengan adanya model pembelajaran yang bisa mempengaruhi hasil belajar siswa, oleh karena itu guru hendaknya dapat menggunakan model-model yang lain supaya siswa dapat lebih interaktif lagi dalam proses belajar mengajar di kelas.

2. Untuk siswa supaya dapat mengikuti pelajaran dengan lebih rajin lagi dan lebih memperhatikan lagi apa yang disampaikan guru agar supaya hasil belajar lebih maksimal.

3. Mengingat masih ada faktor lain yang dapat mempengaruhi motivasi belajar siswa di MA YKDC Sumedang, maka hendaknya dilakukan upaya yang optimal dalam dalam meningkatkan berbagai aspek yang sekiranya dapat mempengaruhi aktivitas dan motivasi belajar mereka di sekolah. Dengan demikian, hendaknya guru atau pihak sekolah memperhatikan faktor lain di lingkungan sekolah, keluarga ataupun masyarakat. Misalnya guru atau pihak sekolah mengadakan hubungan yang baik dengan orang tua siswa tersebut tinggal, sehingga guru bisa mendapatkan informasi dan memantau keadaan siswa di luar sekolah. 


\section{REFERENSI}

Abdorrakhman Gintings. Esensi Praktis; Belajar dan Pembelajaran. Bandung: Humaniora. 2010.

Abin Syamsudin Makmun. Psikologi Kependidikan. Bandung: PT Remaja Rosdakarya. 2009.

Amir Syarifuddin. Ushul Fiqh. Jakarta: Kencana. 2008.

Anas Sudijono. Pengantar Statistik Pendidikan. Jakarta: PT Raja Grafindo Persada. 2007.

Hasbi Ash Shiddeqy dalam Nazar Bakry. Fiqh dan Ushul Fiqh. Jakarta: PT. Raja Grafindo Persada. 2003.

M. Ngalim Purwanto. Psikologi Pendidikan. Bandung: PT Remaja Rosdakarya. 2000.

Nanih Machendrawaty dan Aep Kusnawan. Teknik Debat Dalam Islam. Bandung: Pustaka Setia. 2003.

Oemar Hamalik. Proses Belajar dan Pembelajaran. Jakarta: PT. Bumi Aksara. 2009.

Sambas Ali Muludin, Maman Abdurrahman. Analisis Korelasi, Regresi dan Jalur dalam Penelitian. Bandung: Pustaka Setia. 2009.

Sardiman, A.M. Interaksi dan Motivasi Belajar Mengajar. Jakarta: Raja Grafindo Persada, 2008.

Subana, dkk. Statistik Pendidikan. Bandung: Pustaka Setia, 2000.

Sugiyono. Statistika Untuk Penelitian. Bandung: Alfabeta, 2015.

Utomo Dananjaya. Media Pembelajaran Aktif. Bandung: Nuansa. 2012. 